
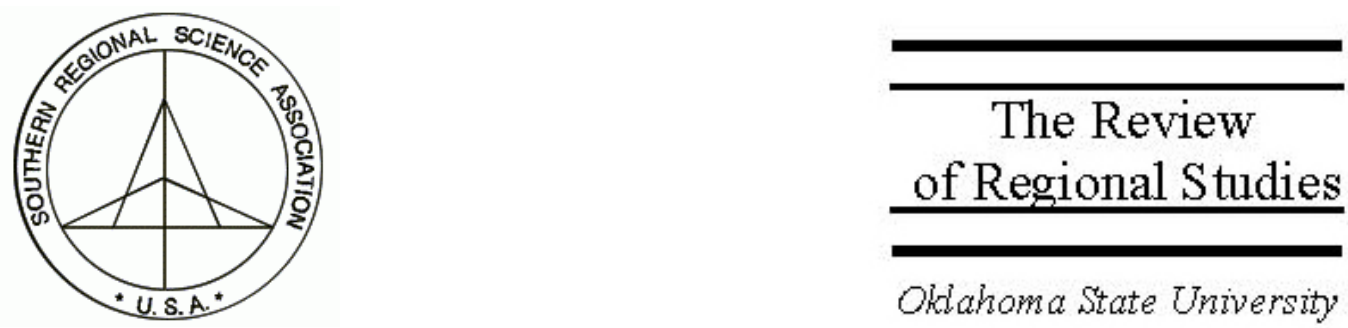

\title{
Spatial Food Stamp Program Participation Dynamics in U.S. Counties
}

\author{
Stephan J. Goetz
}

Northeast Regional Center for Rural Development, The Pennsylvania State University, 7E Armsby Building, University Park, PA 16802-5602, e-mail: sgoetz@psu.edu

\section{Anil Rupasingha}

Department of Economics, American University of Sharjah, P.O. Box 26666, Sharjah, U.A.E., e-mail: arupasingha@ausharjah.edu

\section{Julie N. Zimmerman}

Dept. of Community and Leadership Development, University of Kentucky, 500 Garrigus Bldg., Lexington, KY 40546-0215, e-mail: jzimm@uky.edu

\begin{abstract}
Understanding the factors that account for differences in food stamp expenditure dynamics over space is important not only for potentially improving public policy but also for clarifying the relative roles of factors that are and are not under the control of welfare recipients in determining their ability to move off welfare rolls. This study contributes to the literature by including a better measure of employment opportunities for welfare recipients, allowing for potential endogeneity in the unemployment rate, and by correcting for spatial dependence bias that may result from the clustering of poverty in "pockets."
\end{abstract}

Keywords: Food stamps; County-level; Dynamics; Spatial econometrics

JEL classification: I38; R11

We thank two anonymous reviewers and Dan Rickman for their valuable comments and suggestions for improving the manuscript. This work was supported in part by the Southern Rural Development Center/ ERS-USDA Small Grants Program on research assessing the impacts of welfare reform, and the small grants program of the Joint Center for Poverty Research at Northwestern University and the University of Chicago. 


\section{INTRODUCTION AND RATIONALE}

Food stamp program participation rates and per capita expenditures have fallen dramatically since the inception of welfare reform in 1996, but the rate at which these reductions are occurring is far from uniform across U.S. states and counties. Understanding the factors that account for these differences is important for a number of reasons. They include understanding the relative roles of different factors in explaining declines in food stamp program participation along with potential interactions associated with participation in different welfare programs, ensuring that individuals with particular characteristics are not involuntarily excluded from programs for which they are eligible, and measuring and comparing the effectiveness and impacts of alternative state programs.

A number of studies have been carried out or are underway on the determinants of Food Stamp Program participation. ${ }^{1}$ Prior research has clearly established that both local economic conditions and welfare reform have contributed to the declining numbers of individuals receiving food stamps. ${ }^{2}$ However, previous studies collectively have at least three important potential limitations.

First, the studies use overall unemployment rates as a measure of local economic conditions, while former welfare recipients in fact tend to work primarily in certain sectors of the economy (such as retailing; see, inter alia, Whitener, Gibbs, and Kusmin 2003). More accurate measures of local economic conditions may include job availability or expansion in these specific sectors.

Second, prior studies suffer from potential simultaneous equations bias, because welfare reform has by definition changed labor force participation. Consequently, unemployment rates and earnings are not strictly exogenous. Whether changing labor force participation of the welfare population is important enough to cause endogeneity bias depends on the size of that population relative to the existing labor force. This question needs to be answered empirically.

Third, it is well known that poverty occurs in "pockets," such as in inner cities, Appalachia, Black Belt South, or the Mississippi Delta (e.g., Beale 2004; Wimberley and Morris 2002). Not surprisingly, welfare program participation levels are similarly clustered in a spatial sense (Figure 1). Perhaps less well known is the fact that this is true not only for levels of participation, but also for participation dynamics (i.e., changes in participation over time). Figure 2 (updated from Cook 2000) shows clear spatial concentrations in rates of decline in per capita food stamp benefits between 1995 and 1999 at the

\footnotetext{
${ }^{1}$ See, for example, the work currently being funded by ERS/FANPR, available at http://www.ers. usda.gov/briefing/FoodNutritionAssistance/macro/.

${ }^{2}$ Prior studies conducted at the sub-state level have for the most part failed to examine the effect of welfare recipients' characteristics in explaining caseload changes. For exceptions see Goetz et al. 1999 and Dyk and Zimmerman 2000.
} 
Figure 1. Counties with High Food Stamp Receipts per Capita: 1999

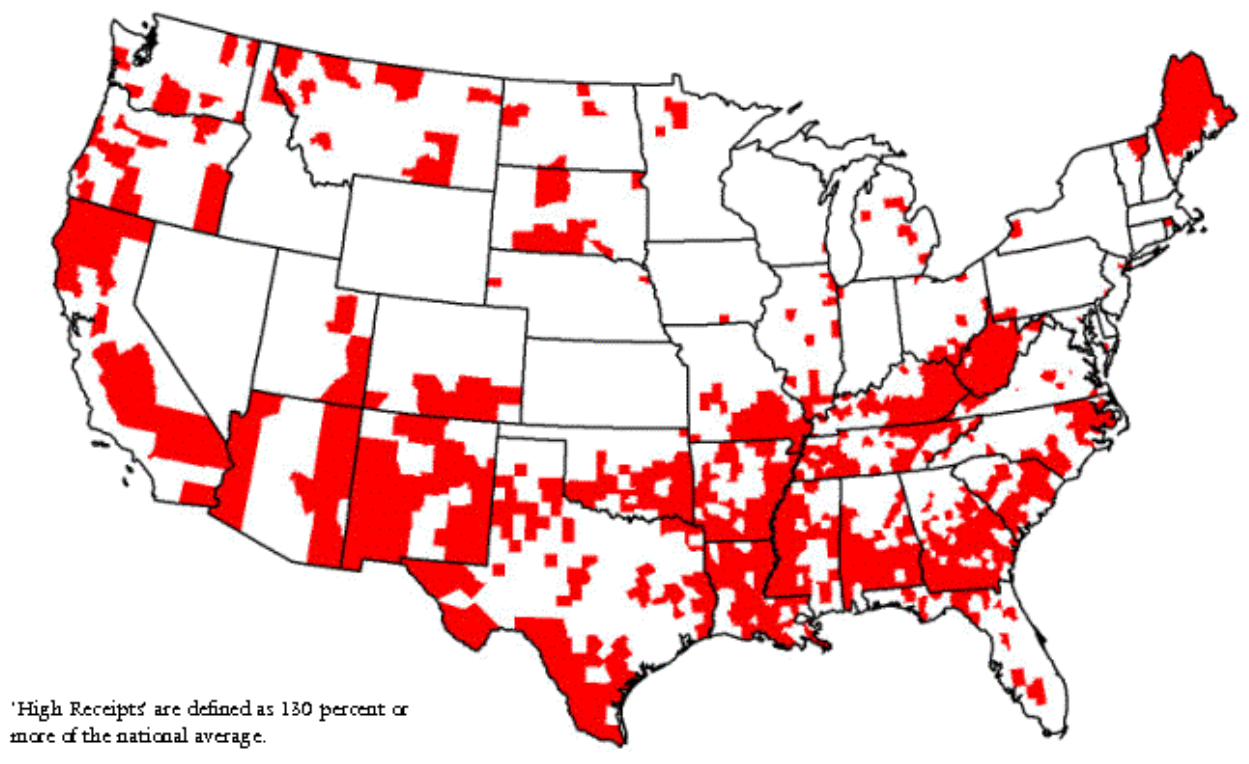

Figure 2. Counties with a Rapid Decline in Food Stamp Receipts per Capita: 1995-1999

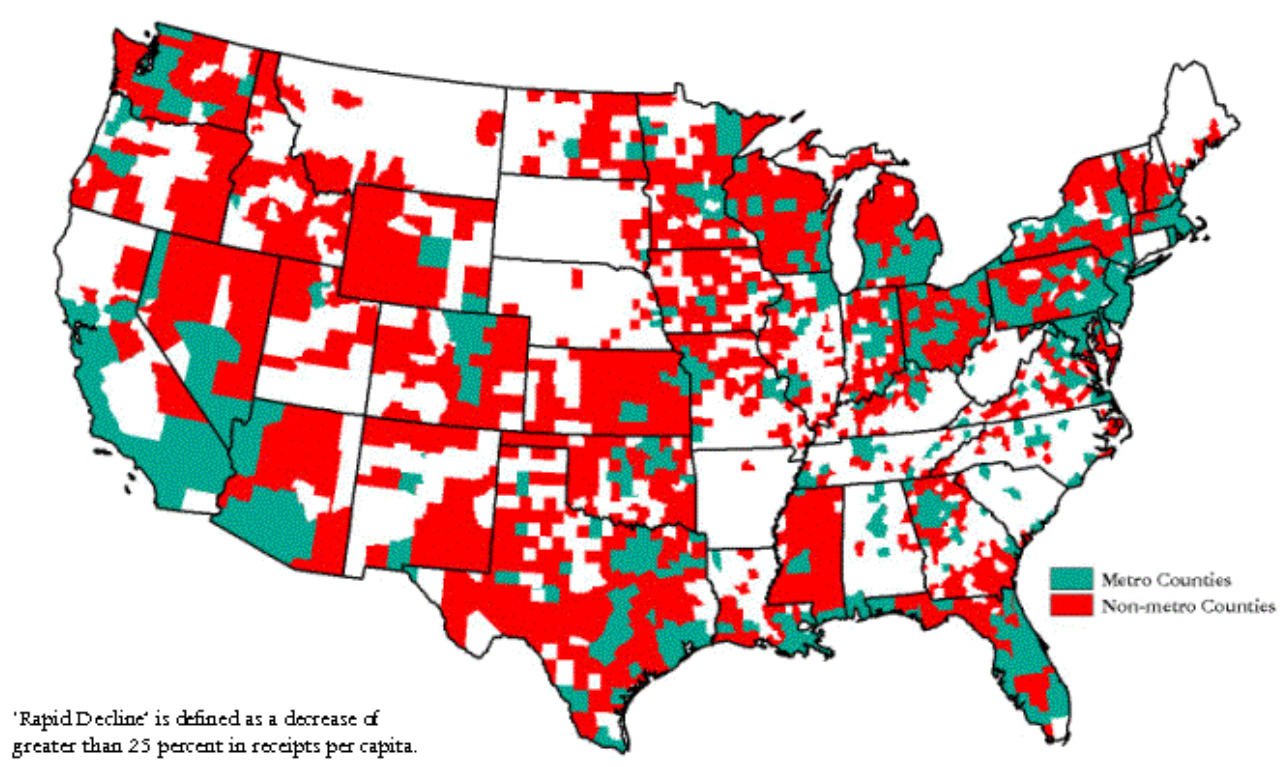


state level. Some of this clustering can be explained by state-level policies (e.g., in Wisconsin or Mississippi), while the clustering - or lack thereof - in Alabama, Pennsylvania, Texas, and Georgia cannot. Yet we are not aware of any prior study that econometrically accounts for this important fact, which can lead to biased or inefficient coefficient estimates in linear regression analysis and, as a result, policy recommendations that may be misleading or may not produce desired outcomes.

We rectify each of these potential limitations in previous studies using county-level secondary data and drawing on relatively recent advances in spatial econometrics. In the process, we also examine interactions between the food stamp and the AFDC/TANF programs with respect to participation and budget exposure as well as the effects of the local (macro-) economic environment on the level of participation and food assistance program costs.

\section{LITERATURE SYNOPSIS}

The effect of macroeconomic changes on cash assistance caseloads (in some cases including food stamp program participation) has been studied by Ziliak et al. (2000); Martini and Wiseman (1997); Blank (1997); Danziger (1999); Wilde et al. (2000); Jacobson et al. (2001); Schoeni and Blank (2000); Figlio, Gundersen, and Ziliak (2000); and Grogger (2001), among others. Overviews of studies examining the relationship between macroeconomic conditions and welfare reform are contained in Dion and Pavetti (2000), Danziger (1999), and Figlio and Ziliak (1999). The Council of Economic Advisors (CEA 1997) reported that more than 40 percent of the reduction in caseloads was the result of the economic expansion (falling unemployment rates), while nearly one-third was the result of welfare reform. Using Current Population Survey data, Moffitt (1999) found similar effects. Wallace and Blank (1999, p. 84) included political and demographic variables and concluded "the ongoing decline in unemployment rates can explain about 8-9 percent of the AFDC caseload declines since 1994." Henry and Lewis (1999) used the same approach at the county level in South Carolina with similar variables and obtained results comparable to those found in national analyses. Bartik and Eberts (1999), finally, also found that variables such as job growth and the industry mix are important predictors of welfare caseload changes.

Similar results have been found in research examining the determinants of food stamp caseloads. Using state-level data, Hansen and Gundersen (2002), for example, found that a one-percentage point increase in the state-level unemployment rate led to a 3-4 percent increase in food stamp caseloads. Wilde et al. (2000) also found that a strong economy accounted for 35 percent of the national food stamp caseload decline from 1994-1999, while program and political factors accounted for 12 percent. Kornfeld (2002), on the other hand, found that the economy accounted for 20 percent of the food stamp caseload decline during this same time, while changes associated with TANF accounted for 21 percent. 
Other studies suggest that there are limits to the ability of the labor market to absorb welfare recipients (Lerman, Lopresta, and Ratcliffe 1999; Goetz and Freshwater 1997) or that the effects of the labor influx could be large for "labor sub-markets" (Bartik 1999). Surveys in various states demonstrate that former recipients are more likely to be employed in specific sectors such as food services and retail (Brauner and Loprest 1999) rather than broadly across all labor markets of the economy (Acs and Loprest 2001). Our own research (Goetz et al. 1999) suggests that variables such as (lagged or contemporaneous) growth in retail and service sector employment or growth serve as measures of how easily former welfare recipients can find employment locally. Another measure we have employed successfully in previous county-level work is the number of retail jobs per capita, as a proxy for job availability created by labor turnover (op. cit). Different economic sectors are also impacted to varying degrees by the business cycle (Holzer 1999). Hoynes (1996, p. 50) found a significant relationship between local labor market conditions and welfare spells: "Minorities, residents of urban areas, and twoparent families are more sensitive to changes in local labor market conditions."

The Rural Policy Research Institute provides a framework for delineating some of the factors differentiating rural and urban areas (RUPRI Rural Welfare Reform Research Panel 1999). These differences include lower educational levels with fewer opportunities for training, less access to and availability of formal child care as well as health care, older and poorer-quality housing stocks, and less rental property as a share of all available housing. All of these variables can be measured at the county level using either U.S. Census (in Census years) or County Business Patterns data (available annually), or they can be captured by a rural indicator variable.

Travel to work, school, grocery, childcare, health care, and other services covers more miles in rural areas, sometimes over difficult terrain. In rural areas, public transportation is most often a rarity. According to the Federal Highway Administration (FHA), 80 percent of nonmetro counties do not have public transportation compared to only 2 percent of metro counties (FHA 2001). Pucher and Bloustein (2004), moreover, found the greatest rural/urban differences among the poor, who traveled (by 59 percent) more miles per day than did their urban counterparts. As a result, personal ownership of a reliable vehicle is important to ensure access to markets and services (Raphael and Rice 2000). And finally, in small communities, networks tend to be smaller and more integrated. While for some this serves as an informal system of support, the system also requires reciprocation in kind. These same networks can impede an individual's advancement as family reputations (beyond an individual's actions) influence local hiring decisions (Duncan 1999). Small networks can also diminish willingness to participate in programs that are associated with a stigma regardless of need or eligibility.

Industrial restructuring, which has been widespread in many rural areas, is linked to increases in female household headship (McLaughlin, Gardner, and Lichter 1999) and poverty (Albrecht, Mulford Albrecht, and Albrecht 2000). Labor market research further indicates that opportunities for advancement in rural areas are more limited (Findeis and 
Jensen 1998), minimum wage employment is more common (Parker and Whitener 1997), and the working poor more numerous (Jensen, et al. 1999).

\section{METHODS}

\subsection{Specification}

Econometric models can be used to investigate the independent impacts of economic conditions facing food stamp recipients, individuals' characteristics, and state policies on food stamp expenditure levels and changes in counties. Our research extends prior analyses in relation to factors listed in the introduction, including an important methodological contribution by correcting for spatial dependence bias.

Further, to test for endogeneity in the contemporaneous change of the unemployment rate and earnings in the estimation, we treat the unemployment rate and earnings as endogenous and create instruments for these variables from auxiliary regressions. We investigate the possibility that initial per capita AFDC/TANF expenditures and contemporaneous changes in such expenditures influence per capita food stamp expenditure changes over time. We thus include changes in per capita AFDC/TANF expenditures as an endogenous regressor within the food stamp expenditure equation, using appropriate instruments to obtain predicted values of the regressor. The well-established literature on labor market hysteresis guides the specification of the unemployment and earnings equations. In particular, Goetz and Freshwater (1997) present county-level models in which wages and unemployment rates are determined simultaneously. We use these models to obtain instruments for the unemployment rate and earnings equations, thereby merging elements of labor market theory with theories pertaining to food stamp expenditure dynamics:

$$
\Delta \mathrm{fsp}=\mathrm{f}(\Delta \mathrm{u}, \Delta \mathrm{epc}, \Delta \mathrm{tnf}, \mathbf{x})+\varepsilon_{1}
$$

Here $\Delta \mathrm{fsp}$ is the change in per capita food stamp expenditures over time, $\mathrm{f}$ is the function to be estimated econometrically, $\Delta \mathrm{u}$ the (predicted) change in the unemployment rate, $\Delta$ epc (predicted) change in per capita earnings, $\Delta$ tnf (predicted) change in AFDC/TANF expenditures per capita, $\mathbf{x}$ a set of exogenous regressors, and $\varepsilon$ an error term.

In addition, we test for spatial dependence in the regression using as one possibility a spatial autoregressive model, which is appropriate when spatial dependence operates through a spatial lag in the dependent variable (y):

$$
\begin{aligned}
& y=\rho \Omega y+Z \beta+\varepsilon \\
& \varepsilon \sim N\left(0, \sigma^{2} I_{n}\right)
\end{aligned}
$$

where $\mathrm{y}$ is an $\mathrm{nx} 1$ vector of dependent variable, $\mathrm{Z}$ represents an nxk matrix containing the determinants of $y$, and $\Omega$ is a spatial weights matrix. Scalar $\rho$ is spatial autoregressive 
parameter and $\beta$ denotes the $\mathrm{k}$ parameters to be estimated for the explanatory variables. The other specification we explore is the spatial error model. This specification is relevant when the spatial dependence operates through the disturbance term (e).

$$
\begin{aligned}
& y=Z \beta+e \\
& e=\lambda \Omega e+\varepsilon \\
& \varepsilon \sim N\left(0, \sigma^{2} I_{n}\right)
\end{aligned}
$$

where $\lambda$ is a scalar spatial error coefficient.

If there were evidence that spatial dependence exists in both forms, through spatial lag and error terms, we could estimate the general spatial model (SAC). The SAC model includes both the spatial lagged term as well as a spatial error structure:

$$
\begin{aligned}
& \text { (7) } \mathrm{y}=\rho \Omega_{1} \mathrm{y}+\mathrm{Z} \beta+\mathrm{e} \\
& \text { (8) } \mathrm{e}=\lambda \Omega_{2} \mathrm{e}+\varepsilon
\end{aligned}
$$$$
\text { (9) } \quad \varepsilon \sim \mathrm{N}\left(0, \sigma^{2} \mathrm{I}_{\mathrm{n}}\right)
$$

LeSage (1999) suggests that we might rely on this model if there is evidence that spatial dependence existed in the error structure from a SAR estimation. An LM test is carried out to see if spatial dependence exists in the residuals of an SAR model. This test differs from the Moran's-I or any other asymptotically valid tests that are carried out to see whether spatial dependence is present in the residuals from least-squares regression model.

The functional form is assumed to be linear, and selection of explanatory variables is guided by previous studies. As noted earlier, we include change in per capita AFDC/ TANF expenditures to determine whether cross-program synergies exist in terms of per capita food stamp expenditure changes (equation 10 below). In addition, and as discussed above, we consider not only an expanded but also a more refined set of variables that are expected to be associated with differences in food stamp program dynamics. This set of variables includes the following.

1. Local economic conditions [A] that are hypothesized to influence changes in food stamp program participation. In particular, this includes measures that are specific to the industries in which former welfare recipients are most likely to find employment (notably the retail industry): job availability as measured by the ratio of retail employment to total employment, as well as the unemployment rate. In addition, we make innovative use of county-level measures such as the total number of child-care establishments [Standard Industrial Classification 
(SIC) code 8350] available per capita in a county, availability of job training centers [SIC 8330], intercity and rural public bus services [SIC 4130], etc., using County Business Patterns data from the U.S. Census Bureau. We also included standard measures reflecting the rural (non-metro, metro non-adjacent), "suburban" (non-metro, metro adjacent - the excluded category), and the urban status of each county.

2. Measures [B] that proxy for the characteristics of the welfare-recipients, including their race, gender, income educational status, residence, and other variables that are available from secondary sources (such as characteristics correlated with program eligibility). Note that we do not have characteristics of the recipient population per se, but that we characterize the "typical" county population from which the recipients are drawn.

3. Variables $[\mathbf{C}]$ that reflect statewide policy differences, cross-program effects, and the political leanings of elected representatives. ${ }^{3}$

We measure change in per capita food stamp expenditures ( $\Delta$ fsp) over the 1995-1999 period. Thus, our dependent variable reflects an intensity of program use within the population rather than actual counts of individuals, but this also focuses attention on the effects of various regressors on government coffers (multiplying the dependent variable by the county population yields total [federal] expenditures on food stamps):

$$
\Delta \mathrm{fsp}=\mathrm{g}(\Delta \mathrm{u}, \Delta \mathrm{epc}, \Delta \mathrm{tnf}, \mathbf{A}, \mathbf{B}, \mathbf{C})+\mathrm{e}
$$

where $\mathrm{e}$ is an error term and the other variables were defined previously.

We employ the empirical specifications in Goetz and Freshwater (1997) to obtain instruments for the contemporaneous change in the unemployment rate, which is a function of the initial unemployment rate in 1995, change in total income between 1995 and 1999 , percent of population over 25 years old who are high school graduates in 1990, percent of population over 25 years old who are college graduates in 1990, and regional dummy variables for counties in New England, Mideast, Great Lakes, Plains, Southeast, Southwest, and Rocky Mountains, with the Far West being the excluded category. To allow for spatial spillover effects across counties, we also include a spatially lagged value of this instrumented variable in the food stamp dynamics equation.

The change in earnings equation was estimated as a function of initial per capita earnings in 1995, unemployment rate in 1995, percent of population over 25 years old who are high school graduates in 1990, percent of population over 25 years old who are college graduates in 1990, Census industrial employment shares in 1990, percent of African Americans, a county amenity scale (McGranahan 1999), and regional dummy variables. Predicted values for the change in AFDC/TANF expenditure per capita

\footnotetext{
${ }^{3}$ We are indebted to Craig Gundersen for providing many of these variables.
} 
variable were similarly obtained from an auxiliary regression that included as instruments the same variables as were included in reduced form equation for food stamp expenditures per capita.

\subsection{Data}

County-level data are obtained from commonly available secondary sources, including the Regional Economic Information System (Department of Commerce), U.S. Census Bureau, County Business Patterns, Bureau of Labor Statistics, and Department of Agriculture. Sources of state-level policy choices include CEA (1999) and Craig Gundersen. Variables used in the analysis are described in Table 1, while Table 2 presents summary statistics. The data set includes all counties in the contiguous U.S. After accounting for missing values, a total of 2,934 counties were used in the analysis. As noted, the time period for the dependent variable is 1995-1999, and most of the right-side variables are measured in 1995 or 1990, depending on their availability (see Table 1).

\subsection{Estimation Issues}

Initial estimates were obtained in a two-stage process using an instrumental variables method since simultaneity is indicated between changes in the unemployment rate, earnings, and per capita AFDC/TANF expenditures. Although we initially argued that endogeneity might also be suspected between food stamp expenditure and AFDC/TANF expenditure, we were not able to identify a separate equation for the AFDC/TANF variable that is different from the food stamp expenditure equation.

\section{REGRESSION RESULTS}

Regression results based on OLS, instrumental variable (IV) analysis, and IV with spatial correction are shown in Table 3. We follow the criteria outlined in LeSage (1999) to select the appropriate spatial specification for our data. Since the general spatial model (SAC) nests both the SAR and the SEM, we first estimated the SAC model. The results of the SAC estimation showed that the spatial autoregressive parameter $(\rho)$ is negative (no spillover effects in the dependent variable) and, therefore, the spatial error model (SEM) is the most suitable specification for our data. The significant lambda value in the SEM (IV spatial) model indicates that spatial dependence exists in the error term, ${ }^{4}$ so that the instrumental variables (IV) model (OLS) is not appropriate for modeling food stamp

\footnotetext{
${ }^{4}$ A reviewer and the journal editor pointed out that some of the spatial autocorrelation might be attributable to common effects of state policies, which would show up as spatial autocorrelation of the error terms. Because of a collinearity problem (state-specific policy variables are correlated with state fixed effects), we could not estimate the model with state fixed effects to see what happens to the spatial autocorrelation parameter and state policy variables after accounting for state fixed effects. However, as another sensitivity test, we estimated the spatial model without these state-specific variables and the spatial autocorrelation parameter (lambda) was still highly significant. Coefficient lambda with these state-specific policy variables was $0.62(\mathrm{t}=30.68)$, and without state policy variables it was $0.67(\mathrm{t}=37.83)$.
} 


\section{TABLE 1}

\section{Variable Definitions}

\begin{tabular}{|c|c|}
\hline Variable & Description \\
\hline \multicolumn{2}{|l|}{ Dependent } \\
\hline CHFS9599 & Change in nominal per capita food stamp expenditure from 1995 to 1999 \\
\hline \multicolumn{2}{|l|}{ Vector A } \\
\hline RETEMP95 & Per capita retail employment in 1995 \\
\hline UNEM95 & Unemployment rate, 1995 \\
\hline PRDUNEM & Predicted value of unemployment change, 1995-1999 \\
\hline WPRDUNEM & Weighted predicted value of unemployment change, 1995-1999 \\
\hline PCEARN95 & Per capita net earnings 1995 \\
\hline PRDEARN & Predicted per capita earnings change, $1995-1999$ \\
\hline BUS & Intercity and rural public bus services establishments per 10,000 in 1995 \\
\hline DAYC & Child-care establishments per 10000 people in 1995 \\
\hline JTRAIN & Job training centers per 10000 people in 1995 \\
\hline URBAN & Whether county is a metropolitan county, beale $=0,1,2,3$ \\
\hline RURAL & Whether county is a rural county, beale $=5,7,9$ \\
\hline \multicolumn{2}{|l|}{ Vector $\mathbf{B}$} \\
\hline DROP90 & $\begin{array}{l}\text { Percent of people ( } 25 \text { years and over) completing less than } 9 \text { th grade plus persons } \\
\text { completing 9th to grade } 12 \text {, no diploma in } 1990\end{array}$ \\
\hline SOMCOL90 & Percent of persons 25 years and over with some college or associate degree in 1990 \\
\hline BLACK90 & Percent of black population in 1990 \\
\hline FEMHH90 & $\begin{array}{l}\text { Ratio of female headed households with no spouse present to total households in } \\
1990\end{array}$ \\
\hline FBPOP90 & Share of foreign-born population in 1990 \\
\hline OVER6590 & Share of population over age 65,1990 \\
\hline VEHIC90 & Vehicles available per occupied housing unit 1990 \\
\hline \multicolumn{2}{|l|}{ Vector $\mathbf{C}$} \\
\hline STDEM & State legislature - Democratic 1990 \\
\hline STREP & State legislature - Republican 1990 \\
\hline ADASENAT & $\begin{array}{l}\text { Index constructed by ADA that measures the degree of political liberalness in the } \\
\text { state's US Senate delegation, } 1990\end{array}$ \\
\hline GOVDEM & Governor - Democratic 1990 \\
\hline MAXBEN & State level maximum food stamp \& AFDC/TANF benefits for family of 3 \\
\hline EBTI & Whether state has implemented electronic benefits transfer (EBT) system \\
\hline ANYIMP & Whether state has implemented a waiver \\
\hline ABAWD & $\begin{array}{l}\text { Percentage of state's population waived from work requirements for unemployed } \\
\text { able-bodied adults without dependents }\end{array}$ \\
\hline \multicolumn{2}{|r|}{ 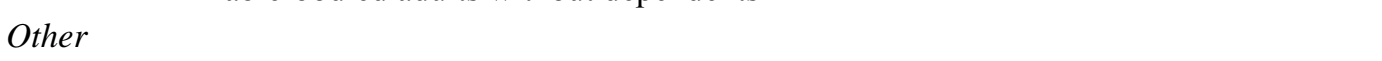 } \\
\hline PCFS95 & Per capita food stamp expenditure level for 1995 \\
\hline PCFA95 & Per capita AFDC/TANF expenditure level for 1995 \\
\hline
\end{tabular}


TABLE 2

Descriptive Statistics

\begin{tabular}{|c|c|c|c|c|}
\hline Variable & Mean & Std. Dev. & Minimum & Maximum \\
\hline CHFS9599 & -0.3705 & 0.2340 & -1.458 & 0.684 \\
\hline RETEMP95 & 0.1611 & 0.0410 & 0 & 0.331 \\
\hline UNEM95 & 6.0601 & 3.0546 & 1.000 & 37.90 \\
\hline PRDUNEM & -1.2444 & 0.9493 & -11.793 & 1.189 \\
\hline PCEARN95 & 11464 & 3544 & 2590 & 40944 \\
\hline PRDEARN & 0.1834 & 0.0315 & 0.0598 & 0.2898 \\
\hline BUS & 1.4102 & 1.9543 & 0.000 & 29.69 \\
\hline DAYC & 1.8196 & 1.2415 & 0.000 & 9.696 \\
\hline JTRAIN & 0.3316 & 0.4962 & 0.000 & 8.565 \\
\hline URBAN & 0.2737 & 0.4459 & 0.000 & 1.000 \\
\hline RURAL & 0.3978 & 0.4895 & 0.000 & 1.000 \\
\hline DROP90 & 30.75 & 10.31 & 5.16 & 68.44 \\
\hline BLACK90 & 0.0886 & 0.1450 & 0.000 & 0.862 \\
\hline FEMHH90 & 0.0987 & 0.0380 & 0.024 & 0.333 \\
\hline FBPOР90 & 0.0220 & 0.0355 & 0.000 & 0.364 \\
\hline OVER6590 & 0.1490 & 0.0426 & 0.014 & 0.341 \\
\hline VEHIC90 & 1.8017 & 0.1907 & 0.250 & 2.570 \\
\hline STDEM & 0.4738 & 0.4994 & 0.000 & 1.000 \\
\hline STREP & 0.3528 & 0.4779 & 0.000 & 1.000 \\
\hline ADASENAT & 39.656 & 35.078 & 0.000 & 100.0 \\
\hline GOVDEM & 0.3732 & 0.4837 & 0.000 & 1.000 \\
\hline MAXBEN & 341.38 & 125.57 & 123.6 & 675.7 \\
\hline EBTI & 0.0100 & 0.0916 & 0.000 & 1.000 \\
\hline ANYIMP & 0.2794 & 0.4242 & 0.000 & 1.000 \\
\hline ABAWD & 0.0083 & 0.0145 & 0.000 & 0.080 \\
\hline PCFS95 & 85.396 & 54.081 & 4.045 & 417.8 \\
\hline PCFA95 & 105.38 & 383.08 & 0.000 & 5826 \\
\hline
\end{tabular}


TABLE 3

Estimation Results

\begin{tabular}{|c|c|c|c|c|c|c|}
\hline \multirow[b]{2}{*}{ Variable } & \multicolumn{2}{|c|}{ Reduced Form Model } & \multicolumn{2}{|c|}{ IV Model } & \multicolumn{2}{|c|}{ Spatial IV Model } \\
\hline & Coeff. & t-ratio & Coeff. & t-ratio & Coeff. & t-ratio \\
\hline Constant & -0.4400 & 3.63 & -0.631 & 4.64 & -0.268 & 1.90 \\
\hline RETEMP95 & -0.3639 & 2.88 & 0.575 & 4.20 & 0.422 & 3.22 \\
\hline UNEM95 & -0.0014 & 0.76 & 0.066 & 10.49 & 0.049 & 8.44 \\
\hline PRDUNEM & & & 0.177 & 10.29 & 0.130 & 8.91 \\
\hline WPRDUNEM & & & & & 0.016 & 1.62 \\
\hline PCEARN95 & $-8.3 \mathrm{E}-06$ & 3.39 & $7 \mathrm{E}-06$ & 2.90 & 0.001 & 0.45 \\
\hline PRDEARN & & & 0.154 & 0.58 & 0.385 & 1.36 \\
\hline BUS & 0.0011 & 0.25 & -0.003 & 0.59 & -0.008 & 2.65 \\
\hline BUS2 & 0.0002 & 0.42 & $1 \mathrm{E}-04$ & 0.22 & 0.001 & 2.22 \\
\hline DAYC & 0.0155 & 1.58 & 0.013 & 1.28 & 0.010 & 1.56 \\
\hline DAYC2 & -0.0015 & 0.79 & -0.001 & 0.32 & -0.001 & 1.16 \\
\hline JTRAIN & 0.0101 & 1.17 & 0.041 & 4.87 & 0.021 & 2.74 \\
\hline URBAN & -0.0238 & 1.90 & -0.021 & 1.79 & -0.012 & 1.17 \\
\hline RURAL & 0.0742 & 7.78 & -0.004 & 0.33 & 1.E-04 & 0.01 \\
\hline DROP90 & 0.0022 & 2.71 & 3.E-04 & 0.30 & -0.001 & 0.74 \\
\hline BLACK90 & -0.3304 & 5.32 & -0.527 & 8.49 & -0.265 & 3.90 \\
\hline FEMHH90 & 1.7946 & 5.32 & 2.789 & 8.75 & 1.568 & 4.96 \\
\hline FBPOР90 & -0.7401 & 4.73 & -1.584 & 7.96 & -0.985 & 5.15 \\
\hline OVER6590 & 0.1097 & 0.72 & -0.028 & 0.19 & -0.174 & 1.23 \\
\hline VEHIC90 & -0.0037 & 0.09 & -0.108 & 2.90 & -0.188 & 5.16 \\
\hline STDEM & -0.0219 & 1.68 & -0.009 & 0.67 & 0.014 & 0.69 \\
\hline STREP & 0.0058 & 0.46 & -0.040 & 3.03 & -0.010 & 0.50 \\
\hline ADASENAT & 0.0004 & 2.24 & 5.E-04 & 3.02 & 0.001 & 2.74 \\
\hline GOVDEM & 0.0515 & 5.19 & 0.037 & 3.61 & 0.034 & 2.36 \\
\hline MAXBEN & -0.0003 & 5.10 & $-4 . E-04$ & 7.22 & -0.004 & 4.76 \\
\hline EBTI & -0.1471 & 4.49 & -0.119 & 3.31 & -0.129 & 2.36 \\
\hline ANYIMP & 0.0882 & 6.84 & 0.142 & 10.66 & 0.114 & 6.56 \\
\hline ABAWD & 1.1614 & 3.39 & 2.400 & 6.67 & 1.316 & 2.44 \\
\hline PCFS95 & -0.0003 & 2.05 & -0.001 & 4.57 & -0.006 & 3.72 \\
\hline PCFA95 & $6.0 \mathrm{E}-05$ & 2.93 & 1.E-04 & 6.19 & 8.E-05 & 5.98 \\
\hline PRDPCFA & & & 0.260 & 10.15 & 0.143 & 4.87 \\
\hline Lambda & & & & & 0.617 & 30.68 \\
\hline Adjusted $\mathrm{R}^{2}$ & & 0.22 & & 0.29 & & 0.48 \\
\hline
\end{tabular}


expenditure, for the time period considered. Significant differences exist between the IV model results and the spatial IV model results. Some of the variables that are significant in the IV model turn out to be insignificant in the spatial model. They are the initial per capita earnings in 1995, the URBAN, and the State legislature - Republican (STREP) variables. On the other hand, bus services establishments per capita (BUS) and its square term (BUS2) that are not significant in the IV model turn out to be significant in the spatial IV model.

The following inference is based on the spatial IV model estimation. The dependent variable is measured as the change in food stamp program payments per capita over time; the mean value of this variable is negative. Therefore, a negative coefficient estimate indicates a greater than average (or faster) decline in payments, while a positive coefficient indicates a smaller than average drop as the value of the variable increases. The regressors in set $[\mathbf{A}]$ - local economic conditions - generally have the expected sign, with the exception of retail employment, earnings, and daycare. These results therefore do not support our initial hypothesis that more jobs in the retail sector will result in lower food stamp expenditures. Both initial and predicted earnings variables are not statistically significant. The day care variable shows an inverted-U relationship after a squared term is added to the regression, but these estimates are not statistically significant. The initial unemployment rate and the contemporaneous change in the predicted unemployment rate are positive and highly significant, as is the effect of the predicted unemployment rate change in surrounding counties (WPRDUNEM in the spatial IV model), confirming findings in other studies that a higher unemployment rate raises food stamp expenditures (or reduced the rate of decline over time). Food stamp payments per capita declined to a lesser degree in counties with more initial job training centers. The URBAN and RURAL indicator variables are not statistically significant.

In terms of the proxies for welfare recipients' characteristics [B], the signs of the estimated coefficients are as expected. In counties with proportionately more AfricanAmericans, food stamp payments per capita fell more quickly. The same was true in counties that had more foreign-born residents, which is not surprising given the provisions of the welfare reform legislation related to non-citizens. Counties with proportionally more households headed by single females experienced a slower decline in per capita food stamp expenditures, while the opposite was true as the number of vehicles per household increased. Access to transportation presumably facilitates the transition into the workforce.

Also reported in Table 3 are the effects of various state-level policies on food stamp program payments (variables in set $[\mathbf{C}]$ ). Results show that having a single-party dominated state legislature did not reduce food stamp payments more quickly or more slowly. Having a Democrat as governor was associated with a smaller drop in food stamp expenditures per capita, and the same is true for political "liberalness" of a state's U.S. Senate delegation. 
Higher beginning-period levels of maximum food stamp and AFDC/TANF payments for a family of three are associated with higher declines in food stamp payments over the period 1995 to 1999. The introduction of electronic benefits transfers (EBTI), unexpectedly, was associated with an accelerated decline in payments, suggesting that the stigmareducing effect of EBTI is inconsequential and more than offset by other effects of EBTI. Welfare reform waivers (ANYIMP) were associated with lower rates of decline in food stamp payments per capita. The percentage of a state's population waived from work requirements for unemployed able-bodied adults without dependents (ABAWD) has a positive effect on per capita food stamp expenditure.

The sign on beginning-period levels of per capita food stamp expenditures is negative and statistically significant. This implies a convergence in food stamp expenditures per capita across counties over time. Counties with higher initial AFDC/TANF payments per capita and higher increases (smaller reductions) in AFDC/TANF expenditures per capita over the 1995-1999 period also had a smaller drop in food stamp per capita expenditures, all else equal, indicating some cross program synergies. ${ }^{5}$

\section{SUMMARY AND POLICY IMPLICATIONS}

These results reveal the systematic effects of spatially varying factors in counties on changes in food stamp program expenditures per capita and over time. For the most part, estimated coefficients have the expected signs. The model reveals statistically significant effects of the initial unemployment rate and changes in the rate on per capita food stamp expenditure at the county level.

Our primary (policy) variables of interest in this study are percent of retail employment, availability of day care facilities, public and taxi services, and job training centers and predicted unemployment rate. The results show mixed effects of these variables on changes in per capita food stamp expenditure at the county level. In the county-level model, correcting for spatial dependence bias has an important effect on the estimated regression parameters.

In addition to the methodological contributions of this research, several notable results of this study stand out for policy makers. Perhaps most important among these is the fact that unemployment rates matter, both as level and as change variables. One policy option here is to encourage welfare recipients to move to counties with better employment prospects. Furthermore, counties experiencing more rapid reductions in AFDC/TANF expenditures per capita also experienced more rapid declines in food stamp expenditures, holding other factors constant.

The regression results do not support our initial hypothesis in terms of retail sector employment. One possible explanation is that welfare recipients living in counties with

\footnotetext{
${ }^{5}$ A number of interaction terms were included in the regression, but they for the most part failed to yield statistically significant coefficient estimates.
} 
more opportunities in that sector feel less pressure to apply for jobs, speculating that they will be available when their eligibility expires. Additionally, the recipients may lack the basic skills needed to fill those positions (the ability to interact with customers, to show up on time for work, etc.). This finding is also compatible with the result for job training - a relatively new variable that has not been widely used in these types of studies. While individuals are in training they may not be working, and the job training available may or may not match the needs of employers in terms of the basic skills just described. More detail is need in terms of the types of job training available, and what kinds of jobs the workers are being prepared to fill.

While day care is critical to securing and retaining employment, the availability of such care may be a feature that is difficult to capture. First, parents on welfare may rely more on family and friends for day care (making it difficult for them to move to counties with more employment opportunities but the lack of a support network for day care purposes). Second, the number of day care establishments does not reflect the number of slots available for children within the establishment.

The URBAN and RURAL variables were not statistically significant, suggesting that whether a county is urban or rural is, by itself, not enough to explain the variation in food stamp expenditures changes when we condition on the other variables shown. This is a potentially important finding for policy makers although we prefer not to read too much into this since some of the variables studied (such as public transportation) exhibit systematically different values in rural as compared to urban areas.

However, the results on the vehicles available stand out as especially notable. Higher rates of vehicle ownership were associated with greater rates of FS expenditure decline, confirming the critical role of car ownership, regardless of place (assuming the cars are working) and after we control for other pertinent factors.

Higher FS/TANF benefit levels are associated with greater declines in food stamp expenditures. This is an important finding since some authors argue that higher benefit levels lead recipients to want to stay on assistance longer and more resistant to leaving. A similar argument is made against raising benefit levels, because that it could lead to inmigration by recipients in search of higher benefits

The result for electronic benefits transfers is curious. It is plausible that seniors and other groups may be less inclined to accept the technology change associated with EBT. Certain establishments also are no longer accepting food stamps due to the need for the EBT card readers. In his small survey of food retailers in Alabama, Zekeri (2003) reported that while they had favorable views of EBT, over half of those interviewed reported having problems with the phone line used by the machine used to read the cards.

In conclusion, while this study sheds considerable light on why food stamp program participation dynamics vary over space, and it shows the importance of incorporating contemporaneous changes in the regressors, a number of significant researchable 
questions remain. It is important to consider and address these questions as welfare reform comes up for reauthorization.

\section{REFERENCES}

Acs, G. and P. Loprest, 2001. "Initial Synthesis Report of the Findings from ASPE's "Leavers" Grants," Report to the U.S. Department of Health and Human Services. The Urban Institute: Washington, D.C.

Albrecht, D.E., C. Mulford Albrecht, and S.L. Albrecht, 2000. "Poverty in Nonmetropolitan America: Impacts of Industrial, Employment, and Family Structure Variables," Rural Sociology 65, 87-103.

Bartik, T.J., 1999. "Will Welfare Reform Cause Displacement?" Employment Research. Spring 1999. W.E. Upjohn Institute for Employment Research: Kalamazoo, MI.

Bartik, T.J. and R.W. Eberts, 1999. "Examining the Effect of Industry Trends and Structure on Welfare Caseloads," pp. 119-157 in Economic Conditions and Welfare Reform, edited by S. H. Danziger. W.E. Upjohn Institute for Employment Research: Kalamazoo, MI.

Beale, C., 2004. "Anatomy of Nonmetro High-Poverty Areas: Common in Plight, Distinctive in Nature," Amber Waves. 2(5), 22-27.

Blank, R.M., 1997. "What Causes Public Assistance Caseloads to Grow?" National Bureau of Economic Research Working Paper 6343: Cambridge, MA.

Brauner, S. and P. Loprest, 1999. Where Are They Now? What States' Studies of People Who Left Welfare Tell Us. Number A-32 in Series, "New Federalism: Issues and Options for States." The Urban Institute: Washington, D.C.

Cook, P., 2000. "Food Stamp and Family Assistance Benefits Sharply Decline in the Post-Welfare-Reform Era," Rural Conditions and Trends 11(2), 68-74.

Council of Economic Advisors. 1997. "Explaining the Decline in Welfare Receipt, 19931996," White House Council of Economic Advisers: Washington, D.C.

Council of Economic Advisors. 1999. "The Effects of Welfare Policy and the Economic Expansion on Welfare Caseloads: An Update," White House Council of Economic Advisers: Washington, D.C.

Danziger, S.H. $1999 a$ ed. Economic Conditions and Welfare Reform. W.E.Upjohn Institute for Employment Research: Kalamazoo, MI.

Danziger, S. 1999b. "Introduction: What are the Early Lessons?" in S. Danziger (ed.), Economic Conditions and Welfare Reform. Upjohn Institute for Employment Research: Washington, D.C., pp. 1-14

Dion, M.R. and L. Pavetti, 2000. "Access to and Participation in Medicaid and the Food Stamp Program: A Review of the Recent Literature," Mathematica Policy Institute, Washington, D.C., March. 
Duncan, C.M., 1999. Worlds Apart-Why Poverty Persists in Rural America, Yale University Press: New Haven.

Dyk, P.H. and J.N. Zimmerman, 2000. "The Impacts and Outcomes of Welfare Reform across Rural and Urban Places in Kentucky." Policy Outcome Grant. Report to the U.S. Department of Health and Human Services, Assistant Secretary for Planning and Evaluation: Washington, D.C.

Federal Highway Administration, 2001. "Planning for Transportation in Rural Areas" (in cooperation with the Federal Transit Administration), U.S. Department of Transportation: Washington, D.C. http://www.fhwa.dot.gov/planning/rural/ planningfortrans/index.html

Figlio, D.N. and J.P. Ziliak, 1999. "Welfare Reform, the Business Cycle, and the Decline in AFDC Caseloads." in S. Danziger (ed.), Economic Conditions and Welfare Reform. W.E. Upjohn Institute for Employment Research: Kalamazoo, MI., pp. $17-48$.

Figlio, D.N, C. Gundersen, and J.P. Ziliak, 2000. "The Effects of the Macroeconomy and Welfare Reform on Food Stamp Caseloads," American Journal of Agricultural Economics 82, 635-41.

Findeis, J., and L. Jensen. 1998. "Employment Opportunities in Rural Areas: Implications for Poverty in a Changing Policy Environment," American Journal of Agricultural Economics 80(5), 1000-1008.

Goetz, S.J., and D. Freshwater, 1997. "Effects of Welfare Reform on Rural Counties and Labor Markets," American Journal of Agricultural Economics 79(5), 838-50.

Goetz, Stephan J. et al., 1999. "Economic Downturns and Welfare Reform: An Exploratory County-Level Analysis," presented at the Small Grants Conference, Food and Nutrition Research Program, ERS/USDA, October 14-15, Washington, D.C.

Grogger, J., 2001. "The Effects of Time Limits and Other Policy Changes on Welfare Use, Work, and Income Among Female-Headed Families," National Bureau of Economic Research Working Paper W8153: Cambridge, MA.

Hanson, K., and C. Gundersen, 2002. "How Unemployment Affects the Food Stamp Program," Food Assistance and Nutrition Research Report Number 26-7. Economic Research Service, U.S. Department of Agriculture: Washington, D.C.

Henry, M., and W. Lewis. 1999. "Changing Welfare Caseloads in South Carolina: Is It the Local Economy, Stupid?" Presented at the Annual Meeting of the Southern Regional Science Association. April 14-17.

Holzer, H.J., 1999. “Will Employers Hire Welfare Recipients?” Focus 20(2), 26-30.

Hoynes, H.W., 1996 "Local Labor Markets and Welfare Spells: Do Demand Conditions Matter?" Institute for Research on Poverty. Discussion Paper No. 1104-96. September. 
Jacobson, J., N. Rodriguez-Planas, L. Puffer, E. Pas, and L. Taylor-Kale, 2001. "The Consequences of Welfare Reform and Economic Change for the Food Stamp Program - Illustrations from a Micro simulation: Final Report," ERS E-FANRR No. 01-003, 98pp, Washington, D.C.

Jensen, L., J.L. Findeis, WL. Hsu, and J.P. Schachter, 1999. "Slipping Into and Out of Underemployment: Another Disadvantage for Nonmetropolitan Workers?" Rural Sociology 64, 417-438.

Kornfeld, R., 2002. "Explaining Recent Trends in Food Stamp Program Caseloads." EFAN 02-008. Economic Research Service, U.S. Department of Agriculture: Washington, D.C.

Lerman, R.I., P. Loprest, and C. Ratcliffe, 1999. How Well Can Urban Labor Markets Absorb Welfare Recipients? Number A-33 in Series, "New Federalism: Issues and Options for States." The Urban Institute: Washington, D.C.

McGranahan, D.A., 1999. "Natural Amenities Drive Rural Population Change." Economic Research Service, U.S. Department of Agriculture, Agricultural Economics Report 781: Washington, D.C.

McLaughlin, D.K., E.L. Gardner, and D.T. Lichter, 1999. "Economic Restructuring and Changing Prevalence of Female-Headed Families in America," Rural Sociology 64, 394-416.

Martini, A., and M. Wiseman, 1997. "Explaining the Recent Decline in Welfare Caseloads: Is the Council of Economic Advisers Right?" Income and Benefits Policy Center. The Urban Institute: Washington, D.C.

Moffitt, R.A., 1999. "The Effect of Pre-PRWORA Waivers on AFDC Caseloads and Female Earnings, Income, and Labor Force Behavior," in S. Danziger (ed.), Economic Conditions and Welfare Reform. W.E. Upjohn Institute for Employment Research: Kalamazoo, MI, pp. 91-118.

Parker, T., and L. Whitener, 1997. "Minimum Wage Legislation: Rural Workers Will Benefit More Than Urban Workers from Increase in Minimum Wage," Rural Conditions and Trends 8, 48-52.

Pucher, J., and J.L. Renne Bloustein, 2004. "Urban-Rural Differences in Mobility and Mode Choice: Evidence from the 2001 NHTS," National Household Travel Survey, April, http://nhts.ornl.gov/2001/articles/UrbanRural.pdf.

Raphael, S., and L. Rice, 2000. "Car Ownership, Employment, and Earnings," Joint Center for Poverty Research Working Paper 179: Chicago, IL.

RUPRI Rural Welfare Reform Research Panel, 1999. "Rural America and Welfare Reform: An Overview Assessment," Rural Welfare Reform Initiative. Rural Policy Research Institute: Columbia, MO. 
Schoeni, R.F., and R.M. Blank, 2000. "What has Welfare Reform Accomplished? Impacts on Welfare Participation, Employment, Income, Poverty, and Family Structure," National Bureau of Economic Research Working Paper W7627: Cambridge, MA.

Wallace, G., and R.M. Blank, 1999. "What Goes up Must Come Down?" in S. Danziger (ed.), Economic Conditions and Welfare Reform. W.E. Upjohn Institute for Employment Research: Kalamazoo, MI, pp. 49-89.

Whitener, L., R. Gibbs, and L. Kusmin, 2003. "Rural Welfare Reform: Lessons Learned," Amber Waves 1(3), 38-41.

Wilde, P., P. Cook, C. Gundersen, M. Nord, and L. Tiehen, 2000. U.S. Dept. of Agriculture, ERS, Food and Economics Division, Food Assistance and Nutrition Report No. 7: Washington, D.C.

Wimberley, R.C., and L. Morris, 2002. "The Regionalization of Poverty: Assistance for the Black Belt South?" Southern Rural Sociology 18(1): 294-306.

Zekeri, A.A., 2003. "Opinions of EBT Recipients and Food Retailers in the Rural South," Southern Rural Development Center, Food Assistance Needs of the South's Vulnerable Populations, Number 6: Starkville, MS.

Ziliak, J.P., D.N. Figlio, E. Davis, and L.S. Connolly, 2000. "Accounting for the Decline in AFDC Caseloads: Welfare Reform or Economic Growth?" Journal of Human Resources 35(3), 417-37. 